\title{
Effects of winter housing systems on production, economics, body weight, body condition score, and bedding cultures for organic dairy cows
}

\author{
B. J. Heins, ${ }^{1 *}$ L. S. Sjostrom, ${ }^{1}$ M. I. Endres, ${ }^{1}$ M. Renato Carillo, ${ }^{2}$ R. King, ${ }^{2}$ R. D. Moon, ${ }^{3}$ and U. S. Sorge ${ }^{4}$ \\ ${ }^{1}$ Department of Animal Science, \\ ${ }^{2}$ Department of Applied Economics, \\ ${ }^{3}$ Department of Entomology, and \\ ${ }^{4}$ Department of Veterinary Population Medicine, University of Minnesota, St. Paul 55108
}

\section{ABSTRACT}

Certified-organic dairy cows $(\mathrm{n}=268)$ were used to evaluate the effect of 2 winter (December to April) housing systems on milk production, somatic cell score (SCS), body weight, body condition score (BCS), and economics across 3 winter seasons (2013, 2014, and 2015). Bedding cultures from the housing systems were also evaluated. Cows were randomly assigned to 2 treatments (2 replicates per group): (1) outdoor (straw pack, $\mathrm{n}=140$ ) or (2) indoor (3-sided compost bedded pack barn, $\mathrm{n}=128$ ). Cows calved during 2 seasons (spring or fall) at the University of Minnesota West Central Research and Outreach Center, Morris, Minnesota, organic dairy. Milk, fat, and protein production and SCS were recorded from monthly milk recording. Body weight and BCS were recorded biweekly as cows exited the milking parlor. Bedding cultures from the housing systems were collected biweekly. Costs for key inputs and the price received for milk production were recorded for the study period and averaged for use in the profitability analysis. Energy-corrected milk and SCS were not different for the outdoor $(15.1 \mathrm{~kg} / \mathrm{d}$, $2.64)$ and indoor $(15.7 \mathrm{~kg} / \mathrm{d}, 2.57)$ housing systems, respectively. In addition, cows in the outdoor and indoor housing systems were not different for body weight (528 vs. $534 \mathrm{~kg})$ and BCS (3.22 vs. 3.23), respectively. Daily dry matter intake was $19.1 \mathrm{~kg} / \mathrm{d}$ for the outdoor cows and $19.6 \mathrm{~kg} / \mathrm{d}$ for indoor cows. The total bacteria count from bedding samples tended to be lower in the outdoor $\left(13.0 \log _{10} \mathrm{cfu} / \mathrm{mL}\right)$ compared with the indoor $\left(14.9 \log _{10} \mathrm{cfu} / \mathrm{mL}\right)$ system. Milk revenue and feed cost were not different for the 2 housing systems. Labor and bedding costs were lower and net return was higher for the outdoor housing system. The outdoor straw pack system had a $\$ 1.42 /$ cow per day net return advantage over the indoor compost bedded pack barn. In sum-

Received February 12, 2018.

Accepted September 7, 2018.

*Corresponding author: hein0106@umn.edu mary, lactating cows housed outdoors on straw-bedded packs did not differ for production or SCS, or for body weight, BCS, or dry matter intake, but had greater profitability than cows housed in an indoor compost bedded pack barn.

Key words: organic, outwintering, compost barn

\section{INTRODUCTION}

Numerous dairy producers from the United States, especially from the Upper Midwest, have turned to an organic production system to capitalize on the higher milk price received for organic milk. The number of organic dairy cattle has increased by $25 \%$ during the past decade (McBride and Greene, 2009), slowing the decline of smaller dairy operations in the Upper Midwest. Similarly, the number of certified organic dairy farms and organic dairy cows in the United States has increased, and Minnesota had over 10,000 certified organic dairy cows in 2011 (USDA, 2014). In 2002, the USDA introduced the National Organic Program (NOP) as a method of standardization for organic agriculture (USDA-NOP, 2016).

The NOP standards became effective in 2002 and address production, certification, recordkeeping, and inputs allowed in organic farming (USDA-NOP, 2016). Pasture and land for production of organic crops must not have had any prohibited substances, such as synthetic fertilizers or pesticides, applied to it $3 \mathrm{yr}$ before the first use of the crop for organic purposes can occur (USDA-NOP, 2016). All certified organic livestock must be fed organic feed from certified organic land. Growth hormones and antibiotics cannot be administered to livestock in organic production systems (Stiglbauer et al., 2013). However, producers cannot withhold medical treatment from a sick animal to keep its organic status. Bedding for livestock must also come from certifiedorganic sources (USDA-NOP, 2016). The USDA-NOP also dictates that organic livestock must maintain living conditions that accommodate the natural behavior of animals. The rules also state that animals must have 
year-round access to the outdoors, shelter, exercise areas, fresh air, and direct sunlight, and continuous confinement is prohibited (USDA-NOP, 2016).

Currently, an increasing number of organic dairy producers are choosing to explore outwintering options for lactating cows. Low cost of production is very important to smaller dairy herds. Famers have expressed interest in outwintering of cattle because of potentially lower cost of production, animal health improvements, and lower machinery costs on farm (Barnes, et al., 2013). The quest for profitability and increased public interest in farm animal welfare have fostered a need to investigate winter housing options for organic dairy cattle.

Housing options for lactating dairy cows in Upper Midwest and northern United States include tiestall barns, freestall barns, compost barns, and outwintering on bedded packs with wind shelters (Barberg et al., 2007b). Beef cows and older nonlactating dairy heifers can thrive with minimal shelter during Minnesota winters (Walker and Mathison, 2008). Compost bedded pack barns have been and are still be used as housing for various dairy herds (Barberg et al., 2007a; Black et al., 2013). Dairy producers with compost bedded pack barns have reported improved cow cleanliness, and most were satisfied with the compost bedded pack barn as a housing system for dairy cows (Black et al., 2013).

No studies have been conducted comparing lactating dairy cows outdoors to those housed indoors during the winter in the United States. The objective of this study was to investigate the effect of 2 wintering systems on BW, BCS, DMI, milk production, SCS, economics, and bacterial pathogens in bedding cultures of organic dairy cows housed indoors in a compost bedded pack barn or outdoors on a straw pack.

\section{MATERIALS AND METHODS}

\section{Experimental Design and Recording of Data}

This study was conducted at the University of Minnesota's West Central Research and Outreach Center (WCROC) Morris, Minnesota, and all animal procedures involving animal care and management were approved by the University of Minnesota Institutional Animal Care and Use Committee (\#1508-32966A). The research dairy at the WCROC operates a 250-cow low-input and organic grazing system.

The study was conducted over 3 winter seasons (December 11, 2012, to April 23, 2013; December 3, 2013, to April 23, 2014; and December 2, 2014, to April 21, 2015). Organic Holstein and crossbred dairy cows were divided into replicated groups balanced by parity, breed, and calving date, and assigned to 2 different housing systems when cows finished the grazing season. Lactating cows averaged $124 \pm 34$ DIM, and were a mix of autumn ( $55 \%$ of cows) and spring ( $45 \%$ of cows) calving cows. The treatments were an outdoor wintering lot (OD) bedded with organic wheat straw, or open-front compost bedded pack barn (ID) with organic-approved sawdust from wood that is not treated with chemicals. The lactating cows were introduced to their respective housing systems after the soil was frozen in December and were removed when pastures were ready for grazing in late April. Throughout the winter, animals were offered the same organically certified TMR that included corn silage, alfalfa silage, dry alfalfa hay, expelled soybean meal, corn, and vitamins and minerals. The ration consisted of $13.7 \% \mathrm{CP}, 36.7 \% \mathrm{NDF}, 3.1 \%$ fat, $1.13 \%$ calcium, $0.36 \%$ phosphorus, $35.9 \%$ NFC, $1.4 \mathrm{Mcal} / \mathrm{kg}$ of $\mathrm{NE}_{\mathrm{L}}$, and $1.5 \mathrm{Mcal} / \mathrm{kg}$ of $\mathrm{NE}_{\mathrm{M}}$. Cows were milked twice daily in a swing-9 para-bone milking parlor at 0600 and $1700 \mathrm{~h}$. Cows were pre-dipped and post-dipped with an $1.0 \%$ iodine-based teat dip. Teats were not dried before cows exited the milking parlor. However, below $-10^{\circ} \mathrm{C}$, cows were post-dipped with an organically approved restricted-use chlorohexidine powder teat dip to prevent frostbite in cows.

Data were collected for 268 organic lactating dairy cows from 3 study years, and cows calved during fall (September to November) or spring (March to May) seasons: $41 \mathrm{ID}$ cows and 42 OD cows during the first year (2012 to 2013) of the study, 43 ID and 44 OD cows during the second year (2013 to 2014) of the study, and $44 \mathrm{ID}$ and 54 OD cows during the third year (2014 to 2015) of the study. More cows were wintered OD during the third year because the organic herd was expanding in size. As the herd expanded in size, more cows were in the outwintering system because the OD lots were greater in size $\left(\mathrm{m}^{2}\right)$ compared with the ID lots. Breed groups of cows include pure Holsteins and various crossbreds of Jersey, Holstein, Montbéliarde, Swedish Red, and Normande, and treatment groups were balanced by breed.

\section{Outdoor Straw Pack}

Two replicated wintering lots (OD cows) were established at the WCROC dairy. Each lot was 0.40 ha in size and contained loafing and feeding areas. Cows had $0.76 \mathrm{~m} / \mathrm{cow}$ of feed bunk space. An existing coniferous tree line on the north side of the lots served as a windbreak. Each lot had a loafing area bedded with organic wheat straw, $12.2 \mathrm{~m}$ wide by $27.4 \mathrm{~m}$ long that was maintained as a bedding pack by adding organic wheat straw as needed to keep the cows dry and effectively absorb manure and urine throughout the winter. Each straw pack provided at least $12 \mathrm{~m}^{2}$ of space per cow. 
Bedding was usually added every 2 to $3 \mathrm{~d}$. Depending on snowfall conditions, bedding may have been added at the bedding pack after a snowfall of at least $5 \mathrm{~cm}$. However, this was infrequent across the winter season. Bedding amounted to about $9 \mathrm{~kg} / \mathrm{cow}$ when added to the straw pack. Cows remained in their lots, except for twice daily milking at the nearby $(30.5 \mathrm{~m})$ milking parlor.

\section{Compost Bedded Pack Barn}

An existing barn at WCROC was divided into 2 independent sections to house the remaining 2 groups of cows (ID cows). The pack was bedded with organicapproved wood chips (1 cm in size). Cows had $0.76 \mathrm{~m} /$ cow of feed bunk space located on a concrete lot outside the compost bedded pack barn. Each barn provided at least $9.5 \mathrm{~m}^{2}$ of space per cow. Initially, 0.45 to 0.61 $\mathrm{m}$ depth of organic-approved sawdust bedding material was added to each replicated section. Thereafter, compost beds were turned twice daily to a depth of 0.18 to $0.24 \mathrm{~m}$ while the cows were being milked, by a cultivator modified to fit on a skid-steer loader. Fresh bedding was added as needed to keep bedding moisture below $60 \%$, which was every 2 to $3 \mathrm{~d}$. Bedding amounted to about $50 \mathrm{~kg} /$ cow when added to the straw pack. During February of each year, about one-half of the bedding material was removed from the pack area to allow more even distribution of bedding across the pack by the skid loader. During harsh winter conditions, the pack may have been more of a bedded pack than an actively composting barn.

Daily feed consumption by each replicated group was the feed offered using a TMR feeding wagon equipped with Feed Supervisor herd management software (Supervisor Systems, KS Dairy Consulting Inc., Dresser, WI). Refusals were not collected with the TMR feeding wagon. Milk production was quantified with monthly measures of milk, fat, protein, SCC, and MUN. To evaluate animal health, cow BW were recorded biweekly using a digital scale (Tru-Test ID5000, Auckland, New Zealand) as cows exited the milking parlor in the morning. Body condition scores were $1=$ excessively thin to 5 = excessively fat, in increments of 0.25 (Wildman et al., 1982) and were manually recorded by one observer at the same time as BW.

\section{Analysis of Bedding Material}

Bedding samples were collected for bacterial analysis every 2 weeks on Wednesday during milking shifts. A composite of 5 bedding surface samples (top $5 \mathrm{~cm}$ ) were collected in each ID and OD area during the morning milking, when the exposure to mastitis causing pathogens was expected to be the greatest. Furthermore, fresh bedding sample (straw and wood chips) was taken every 2 weeks before the material was added to either the ID or OD area. The bedding samples were immediately frozen until analysis by the Laboratory for Udder Health, University of Minnesota College of Veterinary Medicine, St. Paul. Bacterial groups were identified as Bacillus spp., coliforms, Streptococcus spp., and CNS. Bacteria counts were expressed as colony-forming units per milliliter of bedding sample.

\section{Economic Analysis}

Costs for inputs (bedding, feed, labor) and the price received for milk were recorded across the $3 \mathrm{yr}$ of the study and averaged for the profitability analysis. The cost of organic wheat straw for the OD system was $\$ 0.172 / \mathrm{kg}$, and the cost of organic-approved sawdust for the ID system was $\$ 0.154 / \mathrm{kg}$. The costs of feed and labor were the same for both systems, and feed was $\$ 0.330 / \mathrm{kg}$ of DM and $\$ 10.00 / \mathrm{h}$, respectively. Milk price was $\$ 0.738 / \mathrm{kg}$ of milk, which was the mean organic milk price from 2012 to 2015. Construction and machinery costs for the 2 housing systems were not included in the analysis. Construction costs were similar and very low for both systems because the barn already existed on the dairy, and necessary machinery (tractor, bedding spreader, and skid loader) was already on the operating organic dairy farm.

The profitability analysis focused on factors that may have been affected by a choice of housing system. Important determinants of overall dairy enterprise profitability such as land and machinery costs, costs for establishing and maintaining pastures, and costs for labor not associated with winter housing are assumed to be the same for both housing systems and were not included in the analysis. The same tractor and bedding spreader were used for the ID and OD systems to deliver and spread the bedding for cows. Therefore, our measure of profitability for each system was a net return to the fixed factors that may not be affected by housing system. Season-long net return was calculated for each of the 2 replicated groups of cows for each housing system for each year. The net return was measured on a $\$$ / cow per day basis and was defined as net return $=$ milk price $\times$ milk production - feed cost $\times$ DMI - bedding cost $\times$ bedding amount - labor cost $\times$ daily labor. Net return ( $\$ /$ cow per day) was the season-long net return to fixed factors for the cows in a system. Milk price $(\$ /$ $\mathrm{kg})$ was the price of milk and milk production $(\mathrm{kg} / \mathrm{cow}$ per day) was the average daily milk production for cows in a housing system. Feed cost $(\$ / \mathrm{kg})$ was the cost of 
feed and DMI was the average daily feed consumption for cows in each housing system. Bedding cost $(\$ / \mathrm{kg})$ was the unit cost of each bedding type and bedding amount $(\mathrm{kg} / \mathrm{cow}$ per day) was the average quantity of bedding applied daily for cows in each housing system. Labor cost $(\$ / \mathrm{h})$ was the cost of labor and daily labor was the average daily labor required per cow to apply and maintain the bedding in the housing system.

\section{Statistical Analysis}

For statistical analysis of individual cow BW and BCS, independent variables were effects of breed, parity (1, 2, or $3+$ ), year of study (2013, 2014, 2015), housing system (ID or OD), the interaction of housing system and year of study, and 14-d period (BW was recorded every $2 \mathrm{wk}$ ) nested with housing system, along with replicate within year of study and cow within housing system and year of study as a random effect. The autoregressive covariance (CS) structure was used because it resulted in the lowest Akaike's information criterion (Littell et al., 1998).

For statistical analysis of individual cow milk, fat, and protein production, ECM, SCS, and MUN, independent variables were effects of breed, parity $(1,2$, or $3+$ ), year of study, housing system, the interaction of housing system and year of study, along with replicated housing system within year of study and cow within housing system and year of study as a random effect. For daily DMI of groups, housing system and housing system and year of study, along with replicated housing system within year of study was included in the statistical model, along with day of feeding as a repeated measure.

For bacterial analysis of bedding material, all data were log-transformed to adjust for lack of normality. For statistical analysis of bacterial pathogens in clean and soiled bedding, independent variables were effects of year of study and housing system, along with date and replicated system as a random effect. For all analyses, the Mixed procedure of SAS (SAS Institute, 2014) was used to obtain solutions and conduct the ANOVA. All treatment results were reported as least squares means, with significance declared at $P<0.05$.

Net return (\$/cow per day) and all the revenue and cost variables used to calculate net return were the dependent variables in a 2-way ANOVA, with housing system and year as fixed effects. Year of study effects were included in the model to capture the effect of significant variations in weather conditions over the study period. The interaction of housing system and year of study did not explain significant $(P>0.05)$ variation within the model, so it was removed from the statistical model.

\section{RESULTS AND DISCUSSION}

Mean, high, and low temperature and total snowfall for winter months during 2013, 2014, and 2015 at the West Central Research and Outreach Center, Morris, Minnesota, organic dairy weather station are in Table 1. During the first year of the study (2012 to 2013) the average monthly temperatures were near normal; however, a large amount of snowfall $(137.7 \mathrm{~cm} ; 27 \%$ greater) was recorded during that particular winter compared with 30-yr historical averages (Table 1). Conversely, during the second year of the study (2013 to 2014), the United States experienced one of the coldest winter seasons on record. The average daily temperature at the WCROC dairy ranged from -14.4 to $5.0^{\circ} \mathrm{C}$ and snowfall was only $59.1 \mathrm{~cm}$, and the most snow occurred during December 2013 (Table 1). The third year of the study recorded temperatures and snowfall that were similar to the 30 -yr average in western Minnesota.

\section{$B W$ and $B C S$}

Table 2 reviews the mean BW across the 3 yr of the study for ID and OD cows. For BW, the ID (534 kg) cows were not different compared with the OD (528 $\mathrm{kg}$ ) cows. The ID cows and OD cows were not different for BW across the $3 \mathrm{yr}$. The BW from cows ranged from 334 to $781 \mathrm{~kg}$ for ID cows and 360 to $814 \mathrm{~kg}$ for OD cows, and cows in housing systems were not different $(P>0.10)$ for each specific week across the winter season. The range in BW within housing system was high because of the different breed combinations used in the study.

For mean BCS across the 3 yr (Table 3 ), the ID (3.23) cows were not different compared with the OD (3.22) cows. The BCS of cows was not different for cows in both housing systems for each specific year. The BCS of cows ranged from 3.15 to 3.28 for ID cows and 3.13 to 3.30 for OD cows, and cows in housing systems were not different $(P>0.10)$ for each specific week across the winter season. Results for BCS across the winter season were consistent with the results of O'Driscoll et al. (2010), who also reported that ID cows and OD cows had similar BCS. Tucker et al. (2007) found dairy cows housed indoor versus outdoor during the winter in California had similar BCS. Furthermore, Tucker et al. (2007) reported that cows with greater BCS may mitigate the effects of cold, harsh winter weather on cows.

\section{DMI and Milk Production}

Across the $3 \mathrm{yr}$ of the study, mean DMI intake of cows across housing systems was lower $(P=0.001)$ for the first year of the study $(17.9 \pm 0.22 \mathrm{~kg} / \mathrm{d})$ compared 
Table 1. Mean, high, and low temperature and total snowfall for winter months during 2013, 2014, and 2015 at the West Central Research and Outreach Center, Morris, Minnesota, organic dairy weather station

\begin{tabular}{|c|c|c|c|c|}
\hline \multirow[b]{2}{*}{ Year and month } & \multicolumn{4}{|c|}{ Weather variable } \\
\hline & $\begin{array}{l}\text { Mean temperature } \\
\left({ }^{\circ} \mathrm{C}\right)\end{array}$ & $\begin{array}{l}\text { Mean high } \\
\quad\left({ }^{\circ} \mathrm{C}\right)\end{array}$ & $\begin{array}{l}\text { Mean low } \\
\left({ }^{\circ} \mathrm{C}\right)\end{array}$ & $\begin{array}{l}\text { Total snowfall } \\
(\mathrm{cm})\end{array}$ \\
\hline \multicolumn{5}{|l|}{2012 to 2013} \\
\hline December & -8.3 & 11.7 & -23.3 & 27.2 \\
\hline January & -11.1 & 2.8 & -26.1 & 8.9 \\
\hline February & -10 & 1.1 & -28.3 & 48.8 \\
\hline March & -6.7 & 6.1 & -20.0 & 19.8 \\
\hline April & 1.7 & 25.0 & -10.6 & 33.0 \\
\hline \multicolumn{5}{|l|}{2013 to 2014} \\
\hline December & -13.9 & 3.9 & -28.9 & 26.4 \\
\hline January & -14.4 & 4.4 & -31.1 & 7.9 \\
\hline February & -14.4 & 3.3 & -26.7 & 9.1 \\
\hline March & -3.9 & 15.0 & -26.1 & 15.7 \\
\hline April & 5.0 & 25.5 & -10.6 & 0.0 \\
\hline \multicolumn{5}{|l|}{2014 to 2015} \\
\hline December & -5.8 & -3.3 & -10.0 & 4.6 \\
\hline January & -8.3 & -4.4 & -13.3 & 10.9 \\
\hline February & -12.7 & -8.8 & -20.0 & 21.1 \\
\hline March & 0.9 & 5.0 & -6.7 & 22.9 \\
\hline April & 8.9 & 14.4 & 0.0 & 0.0 \\
\hline
\end{tabular}

with the second $(19.9 \pm 0.22 \mathrm{~kg} / \mathrm{d})$ and third $(20.2 \pm$ $0.22 \mathrm{~kg} / \mathrm{d})$ yr of the study.

Least squares means and standard errors for DMI, milk production, SCS, and MUN of cows across the 3 -yr for housing system are shown in Table 4 . The DMI was comparable between ID (19.6 kg/d) and OD (19.1 $\mathrm{kg} / \mathrm{d}$ ) cows, which was unexpected as one would assume that OD cows might consume more DMI than ID cows because they are exposed to harsher environmental conditions. Quite possibly, both ID and OD were not different in this study because the same weather conditions affected cows in both housing systems. The ID system was a 3 -sided barn without insulation and an open side where the cows had to eat outside, which had similar temperature conditions to cows in the OD housing system. The DMI for ID and OD cows was similar for the first $(18.3 \mathrm{~kg} / \mathrm{d}$ versus $17.6 \mathrm{~kg} / \mathrm{d} ; P=$ $0.12)$ and second year $(19.9 \mathrm{~kg} / \mathrm{d}$ versus $19.9 \mathrm{~kg} / \mathrm{d} ; P=$ $0.95)$, respectively. However, during the third year, the ID cows tended $(P=0.06)$ to have greater DMI (20.7 $\mathrm{kg} / \mathrm{d})$ compared with the OD cows $(19.8 \mathrm{~kg} / \mathrm{d})$.

Previous studies have reported cows will spend more time eating in response to cold environmental conditions (Redbo et al., 2001). Webster et al. (2008) reported that dairy cows have lower welfare and increased stress during cold and wet conditions. Typically, thinner

Table 2. Least squares means for BW $(\mathrm{kg})$ across the $3 \mathrm{yr}$ of the study for winter housing systems of organic dairy cows ${ }^{1}$

\begin{tabular}{lccccc}
\hline \multirow{2}{*}{$\begin{array}{l}\text { Measurement for } \\
\text { 14-d period }\end{array}$} & \multicolumn{2}{c}{ Indoor compost bedded pack } & & \multicolumn{2}{c}{ Outdoor straw pack } \\
\cline { 2 - 3 } \cline { 5 - 6 } & Mean BW & SEM & & Mean BW & SEM \\
\hline 1 & 520 & 6.0 & & 516 & 5.8 \\
2 & 524 & 6.0 & & 518 & 5.8 \\
3 & 524 & 6.0 & & 521 & 5.8 \\
4 & 530 & 6.0 & & 523 & 5.8 \\
5 & 528 & 6.0 & & 521 & 5.8 \\
6 & 532 & 6.1 & & 526 & 5.8 \\
7 & 544 & 6.2 & & 538 & 5.9 \\
9 & 539 & 6.3 & & 531 & 6.3 \\
10 & 554 & 7.5 & & 535 & 7.1 \\
Mean of 14-d periods & 540 & 5.8 & & 528 & 5.5 \\
\hline
\end{tabular}

${ }^{1}$ No significant difference $(P>0.05)$ was detected between housing groups for BW for any specific week or the mean of the 14-d periods. 
Table 3. Least squares means for BCS across the $3 \mathrm{yr}$ of the study for winter housing systems of organic dairy cows $^{1}$

\begin{tabular}{|c|c|c|c|c|}
\hline \multirow{2}{*}{$\begin{array}{l}\text { Measurement for } \\
\text { 14-d period }\end{array}$} & \multicolumn{2}{|c|}{ Indoor compost bedded pack } & \multicolumn{2}{|c|}{ Outdoor straw pack } \\
\hline & Mean BCS & SEM & Mean BCS & SEM \\
\hline 1 & 3.24 & 0.03 & 3.27 & 0.03 \\
\hline 2 & 3.29 & 0.03 & 3.31 & 0.03 \\
\hline 3 & 3.25 & 0.03 & 3.33 & 0.03 \\
\hline 4 & 3.24 & 0.03 & 3.22 & 0.03 \\
\hline 5 & 3.21 & 0.03 & 3.19 & 0.03 \\
\hline 6 & 3.15 & 0.03 & 3.17 & 0.03 \\
\hline 7 & 3.14 & 0.04 & 3.14 & 0.03 \\
\hline 8 & 3.25 & 0.04 & 3.14 & 0.04 \\
\hline 9 & 3.27 & 0.05 & 3.24 & 0.04 \\
\hline 10 & 3.23 & 0.06 & 3.21 & 0.06 \\
\hline Mean of $14-d$ periods & 3.23 & 0.02 & 3.22 & 0.02 \\
\hline
\end{tabular}

${ }^{1}$ No significant difference $(P>0.05)$ was detected between housing groups for BCS for any specific week or the mean of the 14-d periods.

cows consume more DMI than cows with greater BCS (Tucker, et al., 2007); however, BCS was not different of cows from both housing systems in this study and this may be a reason why DMI did not differ between cows in housing systems.

The ID cows were not different $(P>0.05)$ from OD cows for any measure of production. Additionally, production measurements were not different for housing groups within specific years of the study. The ID and OD cows were not different for ECM or for FCM. The SCS was similar (2.57 vs. 2.64) for the ID and OD cows. O'Driscoll et al. (2008) reported that cows housed outdoors had similar SCS compared with cows housed indoors, which is in agreement with the current study. The production results are similar to O'Driscoll et al. (2010) who reported cows housed in sheltered outwintering pads had similar fat and protein production to cows housed inside a barn.

\section{Bedding Cultures}

Least squares means for bacterial pathogens in clean and soiled bedding material across the winter season and year for winter housing systems of organic dairy cows are shown in Table 5. The clean straw bedding samples had greater $(P=0.01)$ numbers of Bacillus spp. (10.4 vs. $\left.7.5 \log _{10} \mathrm{cfu} / \mathrm{mL}\right)$, Staphylococcus spp. (5.4 vs. $0.0 \log _{10} \mathrm{cfu} / \mathrm{mL}$ ), and total bacterial load (10.5 vs. $7.6 \log _{10} \mathrm{cfu} / \mathrm{mL}$ ) compared with clean sawdust bedding. It was expected that the clean sawdust bedding would have lower bacterial pathogens because the sawdust was dry before delivery at the WCROC dairy. The wheat straw could have many pathogens from the environment and soil from where it was harvested because the straw was raked into windrows before baling.

Conversely, in soiled bedding samples the opposite results were observed. The straw bedding samples

Table 4. Least squares means for DMI and production across the $3 \mathrm{yr}$ of the study for winter housing systems of organic dairy cows ${ }^{1}$

\begin{tabular}{lccccc}
\hline & \multicolumn{2}{c}{ Indoor compost bedded pack } & & \multicolumn{2}{c}{ Outdoor straw pack } \\
\cline { 2 - 3 } \cline { 5 - 6 } Measurement & Mean & SEM & & Mean & SEM \\
\hline As-fed intake (kg/d) & 41.0 & 0.5 & & 39.9 & 0.5 \\
DMI (kg/d) & 19.6 & 0.2 & & 19.1 & 0.3 \\
Milk (kg/d) & 15.8 & 0.4 & & 15.1 & 0.4 \\
Fat (kg/d) & 0.64 & 0.01 & & 0.63 & 0.01 \\
Fat (\%) & 4.13 & 0.06 & & 4.20 & 0.06 \\
Protein (kg/d) & 0.52 & 0.01 & & 0.50 & 0.01 \\
Protein (\%) & 3.39 & 0.03 & & 3.36 & 0.03 \\
ECM (kg/d) & 15.7 & 0.2 & & 15.1 & 0.2 \\
FCM (kg/d) & 15.9 & 0.3 & & 15.5 & 0.3 \\
SCS & 2.57 & 0.1 & & 2.64 & 0.1 \\
MUN (mg/dL) & 8.2 & 0.1 & & 8.1 & 0.1 \\
\hline
\end{tabular}

${ }^{1}$ No significant difference $(P>0.05)$ was detected between housing groups for DMI or production. 
tended $(P=0.07)$ to have fewer Bacillus spp. (12.1 vs. $\left.14.4 \log _{10} \mathrm{cfu} / \mathrm{mL}\right)$ and fewer $(P=0.03)$ coliforms (6.5 vs. $\left.11.9 \log _{10} \mathrm{cfu} / \mathrm{mL}\right)$ and tended $(P=0.09)$ to have fewer total bacteria (13.0 vs. $14.9 \log _{10} \mathrm{cfu} / \mathrm{mL}$ ) compared with soiled sawdust bedding samples from the compost bedded pack barn. Sawdust and straw bedding samples were not different for environmental streptococci or Staphylococcus spp.

The results for bacterial species load in the compost barn are greater than the results reported by Barberg et al. (2007b), Shane et al. (2010a,b), and Black et al. (2014). However, Black et al. (2014) reported on herds in Kentucky, which had very different climatic conditions during the winter than Minnesota. Furthermore, extreme cold climatic conditions may have contributed to increased bacterial load. Temperature of the ID pack was not collected during the experiment, and the barn has little composting activity. The clean sawdust had $7.6 \log _{10} \mathrm{cfu} / \mathrm{mL}$, which was higher than the average soiled bedding samples reported by Barberg et al. (2007b). Greater than $10 \log _{10} \mathrm{cfu} / \mathrm{mL}$ may indicate an increased risk of mastitis in dairy cows (Lobeck et al., 2012). The results for coliform in this current study were lower than the threshold $\left(10 \log _{10} \mathrm{cfu} / \mathrm{mL}\right)$ for potential mastitis in the OD cows. Regardless, the high bacteria species found in both the ID and OD areas emphasize the importance of superior teat cleaning procedures at the time of milking.

\section{Profitability}

Least squares means and standard errors for bedding ( $\mathrm{kg} /$ cow per day), labor (h/cow per day), net return, milk revenue, feed cost, bedding cost, and labor cost per cow per day across the outwintering season for the ID and OD systems in each of the 3 study years are shown in Table 6 . The ID system used more $(P=0.001)$ bedding and more $(P=0.001)$ labor to bed cows for each of the $3 \mathrm{yr}$ of the study. This cost saving for the OD system was the basis for the OD system's advantage in net profit. Within each housing system, the amount of bedding used and labor were similar across the years of the study.

Milk revenue and feed cost differed $(P=0.01)$ across years, but did not differ between the ID and OD systems because milk production and DMI were not different between the ID and OD housing systems (Table 4). Bedding cost for the ID system was $53 \%$ greater ( $P$ $=0.001 ; \$ 2.50$ vs. $\$ 1.17 /$ cow per day) compared with the OD system. Labor cost was about $\$ 0.10 /$ cow per day greater $(P=0.001)$ for the ID system compared with the OD system, which may have large economic considerations for dairy profitability. Labor cost was greater for the ID system because of the increased labor for tilling the compost pack twice per day. The time required to bed the OD and ID packs was similar. Labor for removal of bedding from both systems at the end of the winter season was not accounted for in the analysis.

Given the differences in bedding and labor cost between housing systems, it is not surprising that net return differed $(P=0.01)$ across years. Mean net return per cow per day was higher $(P=0.04)$ for the OD $(\$ 4.20)$ system compared with the ID $(\$ 2.78 /$ cow per day) system. The $\$ 1.42 /$ cow per day net return advantage for the OD system translates to $\$ 19,880$ in increased net return for a 100-cow dairy operation over a 140-d outwintering season. The net return was greater for the first year of study compared with the second and third year, and differences in profitability between years were driven by variation in feed costs and milk revenue.

Economically, animals in colder climates may require about 10 to $30 \%$ more feed for the season compared with animals kept in a confinement freestall barn housing system (Pastoor et al., 2012), so improvements in animal health and welfare from outwintering will need

Table 5. Least squares means for bacterial pathogens in clean and soiled bedding material across the 3 yr of the study for winter housing systems of organic dairy cows

\begin{tabular}{|c|c|c|c|c|c|c|c|c|}
\hline \multirow[b]{3}{*}{ Variable } & \multicolumn{4}{|c|}{ Clean bedding samples } & \multicolumn{4}{|c|}{ Soiled bedding samples } \\
\hline & \multicolumn{2}{|c|}{$\begin{array}{l}\text { Indoor compost } \\
\text { bedded pack }\end{array}$} & \multicolumn{2}{|c|}{ Outdoor straw pack } & \multicolumn{2}{|c|}{$\begin{array}{l}\text { Indoor compost } \\
\text { bedded pack }\end{array}$} & \multicolumn{2}{|c|}{ Outdoor straw pack } \\
\hline & Mean & SEM & Mean & SEM & Mean & SEM & Mean & SEM \\
\hline Bacillus spp. & 7.5 & 0.7 & $10.4^{* *}$ & 0.7 & 14.4 & 0.6 & $12.1 \dagger$ & 0.5 \\
\hline Coliforms & 4.6 & 0.9 & 6.8 & 2.1 & 11.8 & 0.6 & $6.5^{*}$ & 0.8 \\
\hline Average total bacteria & 7.6 & 0.7 & $10.5^{* *}$ & 0.7 & 14.9 & 0.5 & $13.0 \dagger$ & 0.5 \\
\hline
\end{tabular}

$\dagger P<0.10,{ }^{*} P<0.05,{ }^{* *} P<0.01$ for difference from indoor compost bedded pack. 
Table 6. Least squares means for net return, milk revenue, feed cost, bedding cost, and labor cost by year for winter housing systems of organic dairy cows

\begin{tabular}{|c|c|c|c|c|c|}
\hline \multirow[b]{2}{*}{ Variable } & \multirow[b]{2}{*}{ Year } & \multicolumn{2}{|c|}{$\begin{array}{l}\text { Indoor compost } \\
\text { bedded pack }\end{array}$} & \multicolumn{2}{|c|}{ Outdoor straw pack } \\
\hline & & Mean & SEM & Mean & SEM \\
\hline \multirow[t]{3}{*}{ Bedding $^{\mathrm{b}}(\mathrm{kg} /$ cow per $\mathrm{d})$} & 2012 to 2013 & 16.8 & 0.45 & $7.5^{* *}$ & 0.45 \\
\hline & 2013 to 2014 & 15.3 & 0.45 & $6.0^{* *}$ & 0.45 \\
\hline & 2014 to 2015 & 16.0 & 0.45 & $6.7^{* *}$ & 0.45 \\
\hline \multirow{3}{*}{ Labor $^{\mathrm{b}}(\mathrm{h} /$ cow per d) } & 2012 to 2013 & 0.72 & 0.01 & $0.16^{* *}$ & 0.01 \\
\hline & 2013 to 2014 & 0.71 & 0.01 & $0.14^{* *}$ & 0.01 \\
\hline & 2014 to 2015 & 0.68 & 0.01 & $0.12^{* *}$ & 0.01 \\
\hline \multirow[t]{3}{*}{$\operatorname{Milk~revenue~}^{\mathrm{a}}(\$ /$ cow per $\mathrm{d})$} & 2012 to 2013 & 13.44 & 0.39 & 13.29 & 0.39 \\
\hline & 2013 to 2014 & 10.77 & 0.39 & 10.62 & 0.39 \\
\hline & 2014 to 2015 & 11.42 & 0.39 & 11.27 & 0.39 \\
\hline \multirow[t]{3}{*}{ Feed $\operatorname{cost}^{\mathrm{a}}(\$ /$ cow per $\mathrm{d})$} & 2012 to 2013 & 6.03 & 0.09 & 5.87 & 0.09 \\
\hline & 2013 to 2014 & 6.70 & 0.09 & 6.54 & 0.09 \\
\hline & 2014 to 2015 & 6.76 & 0.09 & 6.60 & 0.09 \\
\hline \multirow{3}{*}{ Bedding $\operatorname{cost}^{\mathrm{b}}(\$ /$ cow per $\mathrm{d})$} & 2012 to 2013 & 2.61 & 0.07 & $1.30^{* *}$ & 0.07 \\
\hline & 2013 to 2014 & 2.36 & 0.07 & $1.05^{* *}$ & 0.07 \\
\hline & 2014 to 2015 & 2.47 & 0.07 & $1.16^{* *}$ & 0.07 \\
\hline \multirow[t]{3}{*}{ Labor $\operatorname{cost}^{\mathrm{b}}(\$ /$ cow per $\mathrm{d})$} & 2012 to 2013 & 0.12 & 0.00 & $0.03^{* *}$ & 0.00 \\
\hline & 2013 to 2014 & 0.12 & 0.00 & $0.02^{* *}$ & 0.00 \\
\hline & 2014 to 2015 & 0.12 & 0.00 & $0.02 * *$ & 0.00 \\
\hline \multirow[t]{3}{*}{ Net return ${ }^{\mathrm{a}}(\$ /$ cow per $\mathrm{d})$} & 2012 to 2013 & 4.68 & 0.43 & $6.10^{*}$ & 0.43 \\
\hline & 2013 to 2014 & 1.59 & 0.43 & $3.01^{*}$ & 0.43 \\
\hline & 2014 to 2015 & 2.08 & 0.43 & $3.49^{*}$ & 0.43 \\
\hline
\end{tabular}

${ }^{\mathrm{a}} P<0.01,{ }^{\mathrm{b}} P<0.10$ for difference across years.

${ }^{*} P<0.05,{ }^{* *} P<0.01$ for difference from indoor compost bedded pack.

to exceed increased feed costs if outwintering is to be a profitable option. Dairy producers have used outwintering in operations because of the low variable cost for housing cattle outdoors (Barnes et al., 2013). Barnes et al. (2013) found that some farmers reported higher costs for outwintering, and the higher costs may be related to poor feed management during this period. The current study found similar results to research studies in Ireland (French et al., 2015) and New Zealand (Beukes et al., 2011) that reported outwintering facilities have the lowest cost and may provide cost-effective ways for producers to house dairy cattle.

\section{CONCLUSIONS}

Outwintering of organic dairy cattle in grazing systems in the Upper Midwest is being explored mostly for its perception of improved animal health and well-being and reduction of labor costs on farm. The current study found OD cows had similar DMI, production, BW, and BCS as ID cows. This study found that cows in the outdoor straw pack system had a $\$ 1.42 /$ cow per day net return advantage over cows in an indoor compost bedded pack barn. The OD system had significantly lower bedding and labor costs. Dairy cows that can tolerate colder temperatures in the northern part of the United States may benefit dairy farms by being housed outdoors to reduce farm expenses, without sacrificing production and animal health and well-being.

\section{ACKNOWLEDGMENTS}

The authors express gratitude to Darin Huot and coworkers at West Central Research and Outreach Center (Morris, MN) for their assistance in data collection and care of animals. Financial support was provided for this project by The Ceres Trust (Chicago, IL) and this work is supported by Organic Agriculture Research and Extension Initiative [grant no. 2012-51300-20015/ project accession no. 0230589] from the USDA National Institute of Food and Agriculture (Washington, DC).

\section{REFERENCES}

Barberg, A. E., M. I. Endres, and K. A. Janni. 2007a. Dairy compost barns in Minnesota: A descriptive study. Appl. Eng. Agric. 23:231-238. https://doi.org/10.13031/2013.22606.

Barberg, A. E., M. I. Endres, J. A. Salfer, and J. K. Reneau. 2007b. Performance and welfare of dairy cows in an alternative housing system in Minnesota. J. Dairy Sci. 90:1575-1583. https://doi.org/ 10.3168/jds.S0022-0302(07)71643-0.

Barnes, A. P., H. McCalman, S. Buckingham, and S. Thomson. 2013. Farmer decision-making and risk perceptions towards outwintering cattle. J. Environ. Manage. 129:9-17. https://doi.org/10.1016/ j.jenvman.2013.05.026.

Beukes, P. C., P. Gregorini, A. J. Romera, and D. E. Dalley. 2011. The profitability and risk of dairy cow wintering strategies in the 
Southland region of New Zealand. Agric. Syst. 104:541-550. https: //doi.org/10.1016/j.agsy.2011.04.003.

Black, R. A., J. L. Taraba, G. B. Day, F. A. Damasceno, and J. M. Bewley. 2013. Compost bedded pack dairy barn management, performance, and producer satisfaction. J. Dairy Sci. 96:8060-8074. https://doi.org/10.3168/jds.2013-6778.

Black, R. A., J. L. Taraba, G. B. Day, F. A. Damasceno, M. C. Newman, K. A. Akers, C. L. Wood, K. J. McQuerry, and J. M. Bewley. 2014. The relationship between compost bedded pack performance, management, and bacterial counts. J. Dairy Sci. 97:2669-2679.

French, P., K. O. Driscoll, B. Horan, and L. Shalloo. 2015. The economic, environmental and welfare implications of alternative systems of accommodating dairy cows during the winter months. Anim. Prod. Sci. 55:838-842. https://doi.org/10.1071/AN14895.

Littell, R. C., P. R. Henry, and C. B. Ammerman. 1998. Statistical analysis of repeated measures data using SAS procedures. J. Anim. Sci. 76:1216-1231.

Lobeck, K. M., M. I. Endres, K. A. Janni, S. M. Godden, and J. Fetrow. 2012. Environmental characteristics and bacterial counts in bedding and milk bulk tank of low profile cross-ventilated, naturally ventilated, and compost bedded pack dairy barns. Appl. Eng. Agric. 28:117-128. https://doi.org/10.13031/2013.41280.

McBride, W. D., and C. Greene. 2009. Characteristics, costs, and issues for organic dairy farming. ERR-82, Economic Research Service, US Department of Agriculture, Washington, DC.

O'Driscoll, K., L. Boyle, P. French, B. Meaney, and A. Hanlon. 2008 The effect of out-wintering pad design on dirtiness score, somatic cell score and mastitis incidence in dairy cows. Animal 2:912-920. https://doi.org/10.1017/S1751731108001882.

O'Driscoll, K., L. Boyle, A. Hanlon, F. Buckley, and P. French. 2010. The effect of dry cow winter management system on feed intake, performance and estimated energy demand. Animal 4:272-281. https://doi.org/10.1017/S1751731109991005.

Pastoor, J. W., D. D. Loy, A. Trenkle, and J. D. Lawrence. 2012. Comparing fed cattle performance in open lot and bedded confinement feedlot facilities. Prof. Anim. Sci. 28:410-416. https://doi.org/10 .15232/S1080-7446(15)30381-8.

Redbo, I., A. Ehrlemark, and P. Redbo-Torstensson. 2001. Behavioural responses to climatic demands of dairy heifers housed outdoors. Can. J. Anim. Sci. 91:9-15. https://doi.org/10.4141/A00-071.
SAS Institute. 2014. SAS/STAT Software. Release 9.4. SAS Institute Inc., Cary, NC.

Shane, E. M., M. I. Endres, and K. A. Janni. 2010a. Alternative bedding materials for compost bedded pack barns in Minnesota: A descriptive study. Appl. Eng. Agric. 26:465-473. https://doi.org/ $10.13031 / 2013.29952$.

Shane, E. M., M. I. Endres, D. G. Johnson, and J. K. Reneau. 2010b. Bedding options for an alternative housing system for dairy cows: A descriptive study. Appl. Eng. Agric. 26:659-666. https://doi .org/10.13031/2013.32062.

Stiglbauer, K. E., K. M. Cicconi-Hogan, R. Richert, Y. H. Schukken, P. L. Ruegg, and M. Gamroth. 2013. Assessment of herd management on organic and conventional dairy farms in the United States. J. Dairy Sci. 96:1290-1300. https://doi.org/10.3168/jds $.2012-5845$.

Tucker, C. B., A. R. Rogers, G. A. Verkerk, P. E. Kendall, J. R. Webster, and L. R. Matthews. 2007. Effects of shelter and body condition on the behaviour and physiology of dairy cattle in winter. Appl. Anim. Behav. Sci. 105:1-13. https://doi.org/10.1016/j .applanim.2006.06.009.

USDA. 2014. Organic Survey. National Agriculture Statistics Service. April 2016. Accessed Apr. 5, 2017. https://www.agcensus.usda .gov/Publications/2012/Online_Resources/Organics/.

USDA-NOP (National Organic Program). 2016. The Program Handbook: Guidance and Instructions for Accredited Certifying Agents and Certified Operations. Accessed Apr. 5, 2017. http://www.ams .usda.gov/about-ams/programs-offices/national-organic-program.

Walker, R. S., and R. Mathison. 2008. Establishing winter feeding areas for grazing. Accessed Mar. 1, 2017. https://www.yumpu.com/ en/document/view/19629941/establishing-winter-feeding-areas -for-grazing-university-of-.

Webster, J. R., M. Stewart, A. R. Rogers, and G. A. Verkerk. 2008. Assessment of welfare from physiological and behavioural responses of New Zealand dairy cows exposed to cold and wet conditions. Anim. Welf. 17:19-26.

Wildman, E. E., G. M. Jones, P. E. Wagner, R. L. Boman, H. F. Troutt Jr., and T. N. Lesch. 1982. A dairy cow body condition scoring system and its relationship to selected production characteristics. J. Dairy Sci. 65:495-501. https://doi.org/10.3168/jds .S0022-0302(82)82223-6. 